\title{
Discussion on the Innovative Strategy of Enterprise Economic Management in the New Era
}

\author{
Yan Zhang \\ Southwest Minzu University, Chengdu, 610041
}

Keywords: new era, enterprise economic management, innovative strategy

\begin{abstract}
Economic management is an important part of all kinds of management work as well as an important step in the process of enterprise operation. With the rapid development of economy, competition pressure in all walks of life is increasing. In order to obtain better economic benefits, economic management must be put in the first place. At present, economic management has accumulated some experience and achieved good results, but under the new market environment, how to improve economic management strategy is still one of the great challenges that enterprises will face. This paper will be aimed at the innovative strategy of enterprise economic management in the new era to conduct an in-depth analysis.
\end{abstract}

\section{Introduction}

In the new era, market economy of our country is constantly developing and perfecting. The economic development is of the objective and scientific guidance characteristics, which point out direction for the management and development of enterprises. With the constant renewal of economic management mode, it also provides many valuable experiences for enterprises, and promotes their rapid and stable development in all aspects. However, at the same time, the social environment faced by enterprises is becoming more and more complex. It is obvious that economic management activities based on experience alone cannot improve economic management ability of enterprises. If enterprises want to stand out in the market environment, it is necessary to innovate economic management according to their actual situation, so as to make enterprises in an invincible position in the market competition.

\section{Connotation of Enterprise Economic Management in the New Era}

Analysis on enterprise economic management combined with management theory has some obvious characteristics. In the processing of relevant information, including Economics, Management and Statistics, the interdisciplinary nature is relatively strong, involving a wide range of information contents and various fields. Economic management plays an irreplaceable role in the management activities of enterprises and plays an important role in promoting their development. Combined with systematic analysis methods, effective economic management can transfer accurate economic information to the managers and decision makers of enterprises on the basis of logical deduction, so as to ensure that economic information can be transmitted to the managers and decision makers and then they can make correct and reasonable investment decisions. That is to say, economic management activities of enterprises affect various types of decision-making, directly relating to the future economic efficiency and sustainable development of enterprises. At the same time, enterprise economic management involves a number of management objects, including cost control, marketing development, production management, logistics management, procurement management and after-sales service etc. In order to achieve the goal of effective management, financial department should be used as the supplementary. Combining with a scientific, perfect and reasonable financial audit system, enterprises are able to make timely and effective control of all business links in accordance with the economic situation.

With the rapid development of China's economy, under the new situation, enterprise economic management activities are included in all parts of enterprise management. Therefore, it is necessary 
to carry out a comprehensive exploration of economic management and innovate enterprise economic management strategies in combining with the new situation and new requirements. Enterprises need to pay attention to the combination of their own actual situation when learning economic management experience, and try to find a sound development route which is suitable for their own. Enterprise economic management in the new era requires not only good efficiency, but also scientific analysis based on statistical theory. Different from the past economic management, innovative economic management mode is capable of ensuring that enterprises can increase additional value in the fierce market competition and create more wealth opportunities, so that enterprises can better survive and develop. Enterprises in the new era need to face more opportunities and challenges. With the increasingly obvious global economic situation, enterprises must actively face all kinds of challenges and go to the world stage if they want to develop and grow. Therefore, in order to meet the requirements of the times and development, it is of great significance for enterprises to actively innovate the economic management mode and improve their overall strength in the industry.

Under the background of new era, many enterprises in our country are facing the challenges brought by industrial transformation and technological renovation. If they are not able to adapt to the new requirements quickly, it may be related to the survival of enterprises. However, if the enterprises themselves have a good transformation ability and scientific approach to economic management that meets their own requirements, they can seize the new opportunities of this era and will not be defeated by the tide of the times. If the enterprises fail to carry on a reasonable optimization reform to the industrial structure, remove the stale thought, or have the problem of waste of resources in the management process, they will lose the market share gradually in the fierce competition and be eliminated gradually by the market. Therefore, in the new era, it is extremely necessary for enterprises to innovate economic management.

\section{Analysis of the Problems Existing in Enterprise Economic Management in the New Era}

In the economic management of enterprises, a huge dilemma is the lack of professional quality of relevant managers, especially the low quality of financial personnel. These problems have a negative impact on the innovation and promotion of enterprise economic management ability. There are also some high-level leaders in enterprises do not have corresponding economic management technologies or theory knowledge. In the implementation of management strategies, it tends to apply empirical and dogmatic mode which makes management has a strong binding characteristic. In addition, some financial personnel always work incompletely and inaccurately in financial related work, so the business situation of enterprises cannot be truly presented, resulting in inaccurate and inefficient economic management, as well as failure in both quality and quantity, putting a negative impact on the economic benefits of enterprises. Relevant professional survey data point out that many managers of enterprises pay too much attention to the economic benefits of enterprise operation, but neglect the training of staff's professional quality and skills, which leads to that the staff cannot effectively carry out various innovations works. Even if a better reform is proposed, nor can it be implemented.

The ultimate goal of enterprise economic management is to improve the economic benefits. In the process of enterprise management, product is the key factor to determine the future development of enterprises. Production technology as the first productive force also has a direct impact. Especially in the current market economy environment, when face the ever-changing market situation, it is very vital for enterprises to provide consumers with better consumer experience and more comfortable services and products that satisfy them. Considering many factors comprehensively, the management mode of enterprises will be affected by various factors. Therefore, enterprises should constantly adjust their own management mode according to the changes and demands of the market, integrate new methods and technologies into the management and production activities, and improve the recognition of the importance to introduce new methods and new technologies, so that their products in the market can always maintain vitality and then achieve sustainable development of enterprises. In the new era, in order to achieve better 
development, enterprises have increased their attention to the added value of products, and have conducted in-depth excavation of the intrinsic value of products, hoping to improve the competitiveness. However, in the introduction of new methods and technologies, because of the impact of traditional management concepts, there are still some problems, which directly lead to a lack of investment and inadequate related resources. In the introduction of new methods and new technologies, there are still some enterprises have not combined with their own situation as well as make unscientific and unreasonable choices, therefore, new technologies in business activities neither can play corresponding effects, nor can achieve the goal of innovation in enterprise economic management.

The perfection, scientificity and rationality of the supervision of accounting department can better help the smooth development of the economic management of enterprises. The accounting work mainly includes the archiving, financial calculation and analysis of important work contents of enterprises, so as to accurately monitor and control the operation of enterprises, and provide data with important reference value for the leaders. But in the actual situation, since the work system of accounting department is not perfect, the audit work is not independent and the accountant post work has the situation which responsibility is not clearly divided, so it is unable to play the role of assistance, affecting the effectiveness of enterprise economic management.

\section{Analysis on the Effective Strategy of Enterprise Economic Management Innovation in the New Era}

The innovation of idea can promote the continuous progress of enterprises and provide a source of power for their development, so innovative idea is also the basis for promoting the development of enterprises. In order to enable enterprises to effectively innovate various mechanisms and form a more powerful driving force, managers and grass-roots staff should actively cooperate with the implement of innovative work, create a good environment for economic management innovation, and build an innovative atmosphere for economic management. Idea innovation can better guide the innovation of actual action, thus improving the mechanism of enterprises. In order to create a better environment for idea innovation, enterprises should take appropriate incentives to guide each employee to be with a good spirit of innovation. When formulating specific implementation plans, relevant managers are suggested to stand at the height of the overall situation with crisis management awareness and strategic awareness, establish a more comprehensive innovative management mode, and apply new technologies and management methods to help enterprises improve competitiveness.

In order to better construct and constantly improve the economic management system, enterprises in the new era are required to pay attention to the innovation of economic management system, so as to provide continuous impetus for promoting the development. In the aspect of system innovation, it is a necessity to pay attention to the construction of a more humane management system. Therefore, enterprises should firstly establish a people-oriented management idea, formulate a reasonable and perfect reward and punishment system, strictly implement the standards, provide a reasonable space for the promotion of management personnel, pay attention to the reserve of personnel, and provide internal support for enterprises' future development. At the same time, combined with the reasonable adjustment of salary system, it can provide employees with good personal development conditions and create a comfortable working atmosphere. Meanwhile, it is also vital to establish a regulatory and decision-making mechanism which is conducive to the participation of the whole staff and the strengthening of the sense of belonging and responsibility of employees to the enterprise. It is also suggested to optimize various resources in the enterprises, meet the needs of institutional innovation, improve the efficiency of employees and stimulate the enthusiasm of employees.

In order to improve the feedback and transmission speed of various information and establish a more compact and flat organizational structure, it is necessary to break through the constraints of traditional management system, strengthen the scope of enterprise management, rationally compress the functional organizations, reduce management level and optimize the speed of information 
transmission. In the aspect of organizational structure innovation, it is worth improving the flexibility and diversity of management organizations, so as to make enterprises more adaptable to the market environment. In the aspect of organizational structure establishment, it is necessary to improve the flexibility of organizational structure. By establishing temporary management institutions, enterprises can get rid of the traditional management mode. With the development of science and technology, enterprises need to properly integrate some computer network technology in management to improve their management ability. By making use of computers, it is possible to manage all kinds of data sets in a centralized way, facilitate the transmission of data statistics, and carry out more scientific analysis of information, so as to improve the efficiency and accuracy of economic management, provide more valuable data for decision-making and ensure the scientificity of decision-making in future development.

\section{Conclusion}

To sum up, if enterprises in the new era want to get better development, it is required to actively innovate the economic management mode. On the contrary, resting on the past achievements will make it difficult to go far away. At present, enterprises are in a constantly changing market environment. If they cannot keep pace with the times, they will be eliminated by the industry, or even the whole industry may be eliminated. In order to develop and grow, they are advised to combine with the actual situation, innovate new economic management mode, raise more requirement to themselves, and make enterprises keep the vitality of sustainable development.

\section{References}

[1] Zhang Ying, Ren Guihong. Research on the Innovation and Practice of Enterprise Economic Management in the New Situation [J]. China Business, 2013, 02:46-47.

[2] Zhang Po. Innovative Strategies of Enterprise Economic Management Model in the New Situation [J]. China Hi-tech Enterprises, 2016, 11:152-153.

[3] Wang Xiaodan. On the Innovation of Enterprise Economic Management in the New Normal [J]. Management and Science and Technology of Small and Medium-sized Enterprises (Later Period Edition), 2016, 04:47-48.

[4] Zhang Xipeng. Innovation Strategy of Enterprise Economic Management in the New Situation [J]. Modern Economic Information, 2013, 21:51-52.

[5] He Huijuan. On the Innovative Strategies of Enterprise Economic Management in the New Situation [J]. China Collective Economy, 2014, 24:51-52. 